\title{
How Do Teachers' Beliefs Predict Children's Interest in Math From Kindergarten to Sixth Grade?
}

\author{
Katja Upadyaya University of Helsinki \\ Jacquelynne S. Eccles University of California
}

\begin{abstract}
The present study investigated to what extent teachers' beliefs about children's achievement contribute to the development of children's math interest. In addition, the extent to which other possible predictors, such as performance in math, gender, and race/ethnicity would contribute to the development of children's math interest was examined. Three cohorts of children $(N=849)$ and their teachers participated in the study starting from kindergarten through their sixth grade. The results showed that especially teachers' beliefs about children's effort and potential performance positively predicted children's interest in math across the primary school years, whereas teachers' beliefs about children's math ability predicted children's math interest only at the beginning of primary school. Further, all the models were similar for boys and girls and for children in different cohort groups.
\end{abstract}

In children's lives, several social actors are very important in shaping children's social experiences, and schools provide an opportunity to investigate these processes in their natural surroundings. In the school context,

\footnotetext{
Katja Upadyaya, Collegium for Advanced Studies; Jacquelynne S. Eccles, School of Education.

This research was funded by grant HD17553 from the National Institute for Child Health and Human Development (NICHD) to Jacquelynne Eccles, Alan Wigfield, Rena Harold, and Phyllis Blumenfeld and supported by a fund from the Finnish Cultural Foundation and the Academy of Finland (no. 126971). The authors would like to acknowledge the help of Alan Wigfield, Rena Harold, Phyllis Blumenfeld, Carol Freedman-Doan, Kwang Suk-Yoon, Amy Arbreton, Rob Roeser, Helen Patrick, Allison Ryan, Cleanthe Mollasis Milojevic, Lisa Colarossi, Dana Johnston, and all the school personnel and families who have contributed to the Childhood and Beyond study since 1986.

Address correspondence to Katja Upadyaya, Researcher, Collegium for Advanced Studies, PO Box 4, University of Helsinki, F-00014 Helsinki, Finland. Phone: +12 488854442. E-mail: katja.upadyaya@helsinki.fi.
}

Merrill-Palmer Quarterly, October 2014, Vol. 60, No. 4, pp. 403-430. Copyright (C) 2014 by Wayne State University Press, Detroit, MI 48201. 
children's experiences with their teachers may contribute to the ontogeny of children's self-perceptions and interest in different domains.

Recent research on academic motivation has highlighted the importance of investigating the value aspect of students' motivation (Jacobs, Lanza, Osgood, Eccles, \& Wigfield, 2002; Upadyaya, Viljaranta, Lerkkanen, Poikkeus, \& Nurmi, 2012), which can be described, for example, in terms of children's interest in different domains (Wigfield \& Eccles, 2000). At the beginning of primary school, children's interest in academic domains is typically high, slightly decreasing over the school years (Jacobs et al., 2002). These changes may reflect normative decreases in children's motivation (Wigfield et al., 1997) and children's better understanding of their academic skills, since children's interests are associated with their competence beliefs and academic performance (Aunola, Leskinen, \& Nurmi, 2006; Eccles, Wigfield, \& Schiefele, 1997; Gottfried, 1990; Murphy \& Alexander, 2000). Moreover, children's interpretations of teachers' achievement-related beliefs and teachers' emotional responses to children shape children's interests. Through their feedback, emotional responses (Georgiou, Christou, Stavrinides, \& Panaoura, 2002; Reyna \& Weiner, 2001), and classroom practices (Stipek, Givvin, Salmon, \& MacGyvers, 2001), teachers provide information regarding their various beliefs about academic achievement to their students. Variation occurs in how teachers' different beliefs predict children's interests and motivation (Natale, Viljaranta, Lerkkanen, Poikkeus, \& Nurmi, 2009; Upadyaya et al., 2012). Yet, to the authors' knowledge, no previous studies have examined these associations over the primary school years. Consequently, the present longitudinal study investigated the extent to which teachers' beliefs about their students' math-related effort, ability, and potential performance, and beliefs about the importance of math, predict the development of first- to sixth-grade children's interest in math.

\section{Interest in Math}

According to the expectancy-value model of motivation (Wigfield \& Eccles, 2000), children's interest in academic domains reflects one element of the value aspect of motivation (Eccles \& Wigfield, 1995). This interest can be described as the inherent, immediate enjoyment one gets from engaging in an activity (Wigfield \& Eccles, 2000). The concept of interest is similar to concepts of intrinsic motivation (Deci, Vallerand, Pelletier, \& Ryan, 1991; Harter, 1981) and interest (Schiefele, 1996), which involve completing a particular task for its own sake. Interest plays an important role in children's motivation: Even if children's beliefs in their abilities (e.g., the expectancy 
aspect of motivation) to perform a specific task are high, they may not involve themselves in that task if they perceive its value to be low (Ryan \& Deci, 2000; Wigfield \& Eccles, 1994). Moreover, children's interests are positively associated with their self-perceptions, competence beliefs, and academic performance (Gottfried, 1990; Murphy \& Alexander, 2000; Wigfield et al., 1997), influencing students' actual engagement in academic domains, particularly in the early school years (Eccles, Adler, \& Meece, 1984; Eccles, Wigfield, Harold, \& Blumenfeld, 1993).

At the beginning of primary school, children's academic interests are differentiated from one another, and their interest values in different domains are typically high (Eccles et al., 1993; Jacobs et al., 2002), slightly decreasing (Wigfield et al., 1997) and gradually stabilizing (Gottfried, 1990; Gottfried, Fleming, \& Gottfried, 2001) over the school years, coinciding with the normative decrease in several aspects of children's academic motivation (Jacobs et al., 2002). These changes in children's interest may be related to declines in children's competence beliefs and academic achievement (Bouffard, Markovits, Vezeau, Boisvert, \& Dumas, 1998), and reflect the development of children's cognitive processing abilities, such as increased ability to make social comparisons and better understanding of evaluative feedback from teachers (Aunola, Leskinen, Onatsu-Arvilommi, \& Nurmi, 2002; Eccles et al., 1997).

Especially at the beginning of children's school career, an important factor affecting the development of their domain interests is their teachers' various beliefs. Already in kindergarten, for example, teachers' beliefs concerning children's achievement predict children's subsequent task motivation (Upadyaya et al., 2012), whereas in early adolescence the role of peers becomes more important (Juvonen \& Murdock, 1995; Wigfield, Eccles, \& Rodriquez, 1998). Similarly, various aspects of the school environment, such as ability groupings, general atmosphere, and the ways teachers give their feedback to children, are reflected in children's motivation (Wigfield et al., 1998). For example, children's interests in different domains are associated with their teachers' interests in various academic activities (Wigfield et al., 1997).

Some studies have also reported gender differences in children's math interest. For example, girls' math interest starts to decline during the primary school years, whereas boys' interest remains higher (Bouffard, Marcoux, Vezeau, \& Bordeleau, 2003). It has been suggested that parents' and teachers' gender stereotypic beliefs antecede gender differences in children's motivation (Frome \& Eccles, 1998; Herbert \& Stipek, 2005; Jacobs \& Eccles, 2000). Consequently, this study investigated the role of various teacher beliefs on children's math interest over the primary school 
years, while controlling for teachers' expectations, children's performance in math, and children's gender, ethnicity, and age.

\section{Teachers' Beliefs About Children's Achievement}

According to the expectancy-value model, teachers are significant socializers whose beliefs about individual children may impact children's own competence beliefs and interests (Eccles et al., 1983). Teachers' beliefs are communicated to children through teachers' feedback, emotional responses (e.g., praise, pity, blame) (Georgiou et al., 2002; Graham, 1990), and classroom practices (Stipek et al., 2001). Teachers are often unaware of the subtle cues that communicate their beliefs (Graham, 1984). For example, a teacher's pity toward a failing student may indicate to the child that he/she lacks the ability to succeed (Georgiou et al., 2002), which may further decrease that student's interest in that domain. Similarly, mastery-focused teachers often create a warm classroom atmosphere, have high confidence in children's abilities, and give children feedback, which promotes understanding rather than performing (Patrick, Anderman, Ryan, Edelin, \& Midgley, 2001), which may further promote children's interest in different domains. Previous studies have typically investigated teachers' expectations regarding children's achievement (Jussim, 1989; Jussim \& Harber, 2005) or teachers' beliefs about the role of children's abilities, effort, task difficulty, and adults' help in academic success and failure (Georgiou et al., 2002; Natale et al., 2009). While ability and effort often are the most common causes to which teachers refer while explaining children's achievement (Weiner, 1992), teachers' other beliefs, such as those concerning children's potential performance (Kärkkäinen \& Räty, 2010) and intrinsic motivation (Gottfried, 1985) have received less attention. These four beliefs were examined further in this study.

Teachers often perceive high-achieving children as having high abilities (Holloway \& Hess, 1985) and needing less help from their teachers (Natale et al., 2009), and highly motivated children as talented and effortful (Upadyaya et al., 2012). However, according to some studies, teachers' beliefs predict children's motivation more often than children's motivational constructs predict teachers' beliefs (Natale et al., 2009; Upadyaya \& Eccles, 2014). Similar findings have been reported among parents (Rytkönen, Aunola, \& Nurmi, 2007). This may occur because, particularly during the early elementary school years, children are sensitive to their significant adults'-for example, teachers'-beliefs and feedback (Eccles et al., 1993; Spinath \& Spinath, 2005). 
Teachers' beliefs also contribute to children's outcomes differently, depending on the content of the belief. For example, teachers' ability attributions for success and beliefs in children's high competence are positively associated with students' actual performance and motivation, whereas attributing children's success to task easiness or teachers' help is negatively associated with children's performance and motivation (Dweck, 1986; Natale et al., 2009). Moreover, teachers frequently encourage children whom they perceive as capable and motivated, which may further increase children's intrinsic motivation (Gottfried, 1985). Teachers are, however, less optimistic than parents about children's potential performance (Kärkkäinen \& Räty, 2010), which may reflect the accuracy of teachers' beliefs (Jussim \& Harber, 2005). Children also typically move from one teacher to another every year, whereas parents may share the same perceptual biases with their children throughout the school years. Thus, by investigating teachers' beliefs further, we may gain knowledge about social actors' beliefs which are less biased.

Students' gender, age, and ethnicity may also influence the ways teachers explain and evaluate children's academic achievement. Boys' success is often attributed to ability and girls' success to effort, especially in mathematics (Madon et al., 1998; Tiedemann, 2002). Moreover, teachers give girls feedback related to the intellectual quality of the girls' work more often than they give feedback to boys (Dweck, Davidson, Nelson, \& Enna, 1978). In addition, teachers tend to attribute White children's problem behavior to situational causes, whereas Black and Hispanic children's problem behavior is typically attributed to child-related causes, such as personality and motivation (Hughes, Gleason, \& Zhang, 2005). While some studies have found that teachers perceive children's academic outcomes accurately regardless of children's ethnic background (Madon et al., 1998), other studies have suggested that teachers are less accurate in rating minority children's academic abilities than the ability of White children and may react differently to the same behaviors exhibited by children from different ethnic backgrounds (Murray, 1996). Further, children interpret teachers' beliefs and feedback according to the children's own understanding of the different causes behind their achievement, which varies with age and other characteristics (Graham, 1990). For example, older children are more likely than younger children to perceive ability and effort as separate characteristics that interact compensatorily (Dweck \& Leggett, 1988; Graham, 1990; Nicholls, 1978). Consequently, the impact of teachers' beliefs and children's gender, age, and ethnicity on children's math interest was examined further. 


\section{Method}

\section{Participants and Procedure}

In this study, we used data from the Childhood and Beyond (CAB) study, in which three cohorts of children and their teachers were followed over many years, beginning in 1986, when the youngest cohort was in kindergarten $^{1}$ (for an overview of the study, see Eccles et al., 1993). Here we used data from Waves 1-4 (i.e., W1-W4) of the study, in which children were followed from kindergarten through sixth grade. The sample consisted of three cohorts of 849 children, of whom 240 were kindergarteners (118 girls and 122 boys), 246 were first graders (126 girls, 120 boys), and 363 were third graders (189 girls and 174 boys) at $\mathrm{W} 1$, and their teachers (W1 $N=102$, W2 $N=81$, W3 $N=127$, and W4 $N=125$ ). The sample consisted of children from middle-class backgrounds who were living in southeastern Michigan who were attending public schools; $92 \%$ of the children were European American.

\section{Children's Measures}

Interest in math. This was examined with a questionnaire three times (W2-W4) during each spring term of the study. Each time, children answered a set of 2-3 questions that included illustrations concerning their math interest-for example, "How much do you like math?" $(1=$ a little, $7=a l o t)$ and "I find working on math assignments ..." $(1=$ boring, 7 = interesting). In W3, an additional question was included: "Compared to other subjects, how much do you like math?" $(1=$ a little, $7=$ a lot $)$ (see Eccles et al., 1993). Sum scores were calculated for children's interest

1. Even though the data were gathered in the 1980s, we believe they are still appropriate for our research questions. If one wants to know whether teachers' beliefs actually predict changes in children's own math interest in real classrooms, then data such as ours are critical. And the date when such data were collected is not likely to influence the conclusions that can be drawn from their analyses. Collecting this type of data is very time consuming and expensive; thus, the opportunity to have such rich data is unusual. Funding agencies are strongly encouraging the use of such data to address basic research questions such as ours, even though the exact nature of instruction in some subject areas may have changed. Whether the fundamental association of teachers' beliefs with the ontogeny of their students' math interest is influenced by the content of what is being taught is an empirical question that should be studied in its own right. Unless the moderating role of differential content or styles of teaching is studied directly, it is typically assumed to be a random source of variation. We believe that making this assumption is warranted and that the findings provide a valid test of the associations we are studying, as would similar data collected in the same schools in 2013 or in another region of the country in the 1980s. 
in math as the mean of the items. The Cronbach's alpha reliabilities for children's interest in math at W2-W4 were .73, .80, and .85.

Performance in math. This was obtained from school reports at the end of each school year (W2-W4). The grades ranged from $\mathrm{F}-$ to $\mathrm{A}+$ and were further coded on a scale of 1-16, where 1 represented an $\mathrm{F}$ and 16 an $\mathrm{A}+$. The math grades for W2-W4 ranged between 5 and $15(M=10.68$, $S D=2.04), 3$ and $15(M=11.43, S D=2.17)$, and 6 and $15(M=11.66$, $S D=1.81)$, respectively.

Demographics. Children's gender was coded $1=$ female, $2=$ male. Cohort status was $1=$ kindergarteners, $2=$ first graders, and $3=$ third graders at W1. Race/ethnicity was coded $1=$ White, $2=$ other $(2.5 \%$ were Asian American, 1.9\% Arab, 1.4\% African American, 1.2\% Asian Indian, $0.5 \%$ Hispanic, and $0.2 \%$ American Indian).

\section{Teachers' Measures}

Teachers' beliefs. Teachers filled in a questionnaire once during each spring term of the study (W2-W4) concerning children's innate ability in math, level of trying and persistence (i.e., effort) in math, perceived importance of math for a child, and the fulfilled potential in math. In the questionnaire, teachers were asked to rate their beliefs concerning each child in their class with a measure of each academic domain, including math-that is, "Compared to other children, how much innate ability or talent does this child have in each of the following?" ". . . how hard does this child try in each activity area listed below?" ". . . to what extent does this child give up when faced with a difficult problem or situation in each of these areas?" ". . . how important does this child think it is to do well in each of the following activities?" and "How well is this child performing in math compared to how well you believe s/he could?" Teachers answered the questions by using a 7-point Likert scale $(1=$ very little, $7=$ a lot $)$.

Teachers' expectations. Teachers rated their expectations (W1) concerning each child in their class (e.g., "How well do you expect this child to do next year in the areas listed below?" with an option for math) by using a 7-point Likert scale $(1=$ very little, $7=$ a lot $)$.

\section{Analytic Strategy}

The research questions were analyzed by using latent growth curve models (LGMs; Duncan et al., 1997) with time-varying covariates. The analyses were carried out in four steps. First, to investigate the extent to which children's interest in math changed across time, an LGM was carried out for 
children's math interest. The observed values of the composite scores for children's interest in math at W2-W4 were specified as a growth model. In the model, the mean level of math interest (intercept), average growth in it (slope), and individual variation across these scores were estimated. The intercept was specified by setting the loadings of the three observed values of math interest to 1 , and the slope was specified by setting the loadings of the three observed values of math interest to 0,1 , and 2, assuming linear growth with equal spacing of assessments over time. The residual variances of the observed variables were allowed to be freely estimated.

Second, to investigate the extent to which teachers' beliefs and children's math performance at each wave would predict the development of children's interest in math, these variables were added to the model as timevarying covariates. A basic model of the study is presented in Figure 1. ${ }^{2}$ Four models were constructed separately for each kind of teachers' beliefs concerning children's achievement in math. Time-varying effects were specified by adding a path from teachers' beliefs at each wave and from children's performance in math at each wave to the observed value of math interest at the same wave. In addition, cross-paths from teachers' previous beliefs and from children's performance at W2 and W3 to children's subsequent interest in math were included for W3 and W4. Because there was a different teacher every year, teachers' belief variables were allowed to correlate with one another over the school years. Similarly, children's performance variables in math were allowed to correlate with one another. Correlations among all the endogenous covariates were also included in the model.

Third, to investigate the extent to which children's gender, cohort status and race/ethnicity, and teachers' expectations (W1) would predict the level and changes in children's math interest, these predictors were included in the models as covariates. Moreover, the impact of these variables on teachers' beliefs and children's math performance was controlled for. Fourth, to examine the possible gender- and age-related differences in the models, multigroup (Jöreskog \& Sörbom, 1993) LGM analyses were carried out.

2. To examine the associations between children's math interest and teachers' beliefs, crosslagged path models were constructed first. These models showed (a) a relatively poor fit; however, the preliminary results indicated that (b) concurrent teachers' beliefs particularly predicted children's math interest (e.g., suggested by the modification indices) and that teachers' beliefs predicted children's math interest more often than vice versa. Thus, to better capture (a) the development of children's math interest and (b) the strongest associations between children's math interest and teachers' beliefs, LGMs with time-varying covariates were carried out. This was the focus of the present study. To control for the impact of children's math performance on teachers' beliefs, all the time-varying endogenous variables were allowed to covary. Moreover, similar cross-lagged associations between teachers' beliefs and children's math performance in the same data set has been partly reported elsewhere (Upadyaya \& Eccles, 2014). 


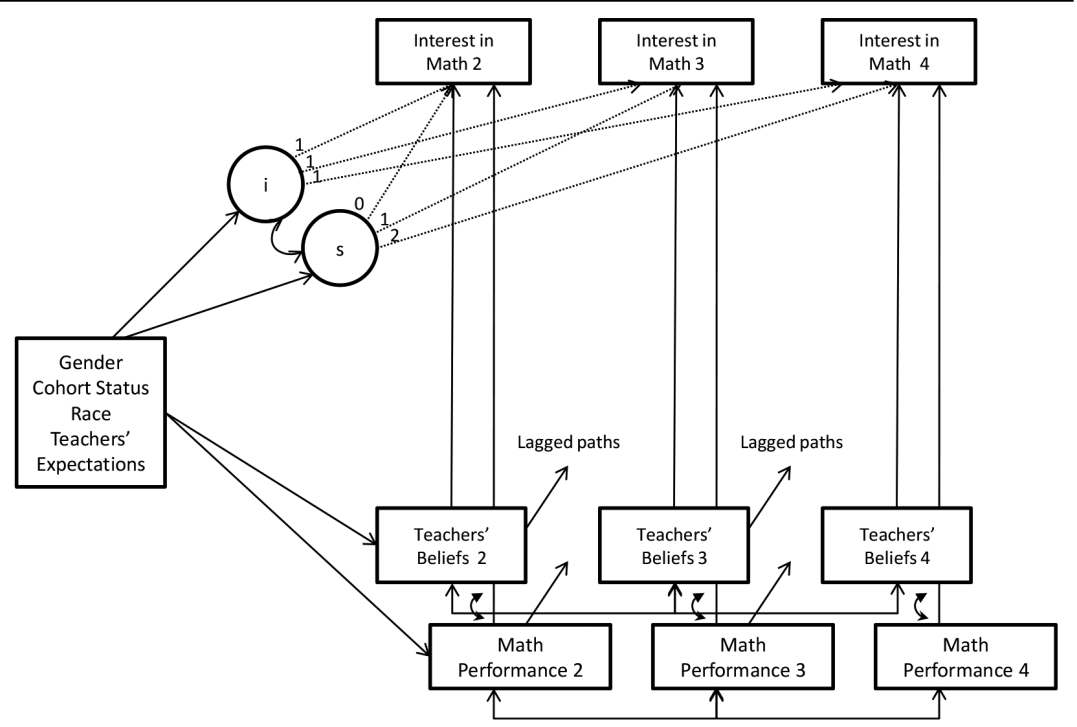

Figure 1. Basic model of the study.

All the analyses were carried out by using the Mplus statistical package (Version 6). Using the missing-data method with the MRL (maximum relative likelihood) estimator (Muthén \& Muthén, 1998-2014), we were able to use all observations available in the data set. The goodness of fit of the estimated models was evaluated by using five indicators: chi-square test, comparative fit index (CFI), Tucker-Lewis index (TLI), root mean square error of approximation (RMSEA), and standardized root mean square residual (SRMR).

\section{Results}

\section{Changes in Children's Math Interest}

First, an LGM was constructed to investigate the mean level, average change, and interindividual variation across these mean components in children's math interest. The model was constructed across three measurement points, and intercept and slope components were specified for each point. The model fit the data moderately well, $\chi^{2}(1, N=1,136)=7.15$, $p=.01, \mathrm{CFI}=.98, \mathrm{TLI}=.93, \mathrm{RMSEA}=.07, \mathrm{SRMR}=.03$. In addition, both the mean and variation were statistically significant for the intercept $(M=4.09, p<.001 ; \operatorname{Var}=1.48, p<.001)$ and slope $(M=-.34$, $p<.001 ; \operatorname{Var}=.38, p<.01)$, indicating significant individual differences 
in both the initial status and developmental trend in children's math interest. The results for children's interest in math suggested that children's interest in math declined during the elementary school years. ${ }^{3}$

\section{Antecedents of Children's Interest in Math}

Next, teachers' beliefs and children's performance were included in the models as time-varying covariates. In addition, children's gender, cohort status, race/ethnicity, and teachers' expectations at W1 were added as covariates to the previous models. The means and standard deviations of teachers' beliefs and of children's math interest and performance are presented in Table 1. The correlations among all of the variables are presented in Table 2. Testing of the models began with estimating all the paths from the predictor variables to the growth components, as well as paths from the time-varying covariates to the observed values of children's math interest. To identify the final models, all the statistically nonsignificant paths were set to zero.

\section{Children's Gender, Cohort Status, and Ethnicity, and Teachers' Expectations}

The results showed first that, in most of the models tested, children's gender, cohort status, and ethnicity predicted the level and linear slope of their math interest: Younger children, boys, and children from groups other than the White ethnic group had a higher interest in math than did children in older cohorts, girls, or those in the White ethnic group (Table 3). In addition, compared to boys and older children, the linear slope of girls' and younger children's interest in math was more negative. Older children also performed better in math than did younger children. Moreover, when teachers' expectations concerning children's future achievement were high, children's math performance was high. Teachers' expectations also positively predicted teachers' beliefs regarding children's effort, abilities, and performance in math, and math importance to children.

\section{Teachers' Effort Beliefs and Children's Interest in Math}

Teachers' effort beliefs were measured with latent variables concerning teachers' beliefs about children's effort and persistence separately at each

3. Jacobs et al. (2002) have reported similar analyses for this sample. 
Table 1. Cohort-specific means and standard deviations of teachers' beliefs, children's math interest, and performance at Waves 2-4

\begin{tabular}{|c|c|c|c|c|c|c|}
\hline & \multicolumn{2}{|c|}{ First cohort } & \multicolumn{2}{|c|}{ Second cohort } & \multicolumn{2}{|c|}{ Third cohort } \\
\hline & $M$ & $S D$ & $M$ & $S D$ & $M$ & $S D$ \\
\hline \multicolumn{7}{|l|}{ Effort ${ }^{t}$} \\
\hline Wave 2 & 5.10 & 1.46 & 5.13 & 1.41 & 5.03 & 1.46 \\
\hline Wave 3 & 4.91 & 1.52 & 5.11 & 1.49 & 4.92 & 1.55 \\
\hline Wave 4 & 5.03 & 1.40 & 4.69 & 1.46 & 4.82 & 1.52 \\
\hline \multicolumn{7}{|l|}{ Ability ${ }^{\dagger}$} \\
\hline Wave 2 & 5.23 & 1.24 & 5.20 & 1.31 & 4.97 & 1.30 \\
\hline Wave 3 & 5.00 & 1.48 & 5.15 & 1.35 & 4.96 & 1.37 \\
\hline Wave 4 & 4.97 & 1.31 & 4.91 & 1.39 & 5.02 & 1.34 \\
\hline \multicolumn{7}{|l|}{ Importance ${ }^{t}$} \\
\hline Wave 2 & 5.58 & 1.36 & 5.65 & 1.39 & 5.44 & 1.41 \\
\hline Wave 3 & 5.33 & 1.44 & 5.69 & 1.37 & 5.39 & 1.49 \\
\hline Wave 4 & 5.63 & 1.43 & 5.30 & 1.35 & 5.40 & 1.47 \\
\hline \multicolumn{7}{|c|}{ Performance $^{t}$} \\
\hline Wave 2 & 5.55 & 1.37 & 5.39 & 1.39 & 5.44 & 1.37 \\
\hline Wave 3 & 5.29 & 1.40 & 5.31 & 1.47 & 5.08 & 1.52 \\
\hline Wave 4 & 5.22 & 1.47 & 5.04 & 1.36 & 4.95 & 1.63 \\
\hline \multicolumn{7}{|c|}{ Math interest } \\
\hline Wave 2 & 5.12 & 2.08 & 4.73 & 2.12 & 4.86 & 1.76 \\
\hline Wave 3 & 5.24 & 1.95 & 4.92 & 2.07 & 4.59 & 1.76 \\
\hline Wave 4 & 4.87 & 1.70 & 4.86 & 1.61 & 4.05 & 1.64 \\
\hline \multicolumn{7}{|c|}{ Math performance } \\
\hline Wave 2 & 10.07 & 1.91 & 10.77 & 2.10 & 11.01 & 2.00 \\
\hline Wave 3 & 10.54 & 1.84 & 11.18 & 2.12 & 12.08 & 2.16 \\
\hline Wave 4 & 10.78 & 1.86 & 11.95 & 1.78 & 12.01 & 1.60 \\
\hline
\end{tabular}

Note . First cohort $=$ kindergarteners, second cohort $=$ first graders, and third cohort $=$ third graders at Wave 1.

'Teachers' belief.

measurement time. After omitting all the nonsignificant paths, the model fit the data well (Table 4). The results showed that when teachers believed children put a lot of effort into math class (W2-W4), the students' concurrent 
Table 2. Pearson correlation coefficients between children's math interest, math performance, teachers' beliefs, and gender and cohort status

\begin{tabular}{|c|c|c|c|c|c|c|c|c|c|}
\hline & 1 & 2 & 3 & 4 & 5 & 6 & 7 & 8 & 9 \\
\hline \multicolumn{10}{|l|}{ 1. Math interest ${ }^{2}$} \\
\hline 2. Math interest ${ }^{3}$ & $.32^{* * *}$ & & & & & & & & \\
\hline 3. Math interest ${ }^{4}$ & $.28^{* * *}$ & $.47^{* * *}$ & & & & & & & \\
\hline $\begin{array}{l}\text { 4. Math } \\
\text { performance } 2\end{array}$ & $.07^{+}$ & $.09^{*}$ & $.12^{* *}$ & & & & & & \\
\hline $\begin{array}{l}\text { 5. Math } \\
\text { performance }\end{array}$ & .05 & $.11^{* *}$ & $.08^{*}$ & $.50^{* * *}$ & & & & & \\
\hline $\begin{array}{l}\text { 6. Math } \\
\text { performance } 4\end{array}$ & $.08^{*}$ & $.09^{* *}$ & $.13^{* * *}$ & $.48^{* * *}$ & $.49^{* * *}$ & & & & \\
\hline 7. Effort ${ }^{2 t}$ & $.14^{* * *}$ & $.07^{+}$ & $.14^{* *}$ & $.37^{* * *}$ & $.26^{* * *}$ & $.32^{\star \star \star}$ & & & \\
\hline 8. Effort ${ }^{3 t}$ & $.09^{*}$ & $.15^{* * *}$ & $.12^{* *}$ & $.27^{* * *}$ & $.41^{* * *}$ & $.31^{* * *}$ & $.46^{* * *}$ & & \\
\hline 9. Effort ${ }^{4 t}$ & $.12^{* *}$ & $.15^{* \star \star}$ & $.20^{* * *}$ & $.23^{* * *}$ & $.34^{* * *}$ & $.33^{* * *}$ & $.46^{* * *}$ & $.49^{* * *}$ & \\
\hline 10. Ability ${ }^{2 t}$ & $.11^{* *}$ & .06 & $.17^{\star \star \star}$ & $.43^{* * *}$ & $.33^{* * *}$ & $.30^{* * *}$ & $.58^{* * *}$ & $.38^{* * *}$ & $.33^{* * *}$ \\
\hline 11. Ability $^{3 t}$ & -.01 & .05 & $.09^{* *}$ & $.34^{* * *}$ & $.41^{* * *}$ & $.34^{* * *}$ & $.40^{* * *}$ & $.63^{* * *}$ & $.35^{* * *}$ \\
\hline 12. Ability ${ }^{4 t}$ & .02 & $.12^{* *}$ & $.13^{* * *}$ & $.30^{* * *}$ & $.37^{* * *}$ & $.38^{* * *}$ & $.39^{* * *}$ & $.45^{* * *}$ & $.60^{* * *}$ \\
\hline $\begin{array}{l}\text { 13. Math } \\
\text { importance }^{2 \dagger}\end{array}$ & $.14^{* * *}$ & $.07^{+}$ & $.17^{* * *}$ & $.33^{* * *}$ & $.21^{* * *}$ & $.28^{\star \star \star}$ & $.79^{* * *}$ & $.42^{* * *}$ & $.42^{* * *}$ \\
\hline $\begin{array}{l}\text { 14. Math } \\
\text { importance }^{3 t}\end{array}$ & $.08^{*}$ & $.13^{* * *}$ & $.10^{* *}$ & $.27^{* * *}$ & $.38^{* * *}$ & $.29^{* * *}$ & $.45^{* * *}$ & $.81^{* * *}$ & $.44^{* * *}$ \\
\hline $\begin{array}{l}\text { 15. Math } \\
\text { importance }^{4 t}\end{array}$ & $.15^{\star \star}$ & $.14^{* \star \star}$ & $.18^{* * *}$ & $.24^{* * *}$ & $.32^{* \star *}$ & $.29^{* * *}$ & $.41^{* * *}$ & $.42^{* * *}$ & $.83^{* * *}$ \\
\hline 16. Performance ${ }^{2 t}$ & $.10^{* *}$ & $.08^{*}$ & $.11^{* *}$ & $.34^{* * *}$ & $.27^{* * *}$ & $.26^{* * *}$ & $.76^{* * *}$ & $.41^{* * *}$ & $.38^{* * *}$ \\
\hline 17. Performance ${ }^{3 t}$ & $.08^{*}$ & $.16^{* * *}$ & $.14^{* * *}$ & $.23^{* * *}$ & $.38^{* * *}$ & $.24^{* * *}$ & $.41^{* * *}$ & $.77^{* * *}$ & $.43^{* * *}$ \\
\hline 18. Performance ${ }^{4 t}$ & $.16^{* * *}$ & $.18^{* * \star}$ & $.25^{* * *}$ & $.27^{* * *}$ & $.33^{* * *}$ & $.34^{* * *}$ & $.41^{* * *}$ & $.44^{* * *}$ & $.80^{* * *}$ \\
\hline 19. Gender & $-.07^{+}$ & .04 & $.07^{*}$ & -.04 & -.04 & .00 & -.05 & $-.06^{+}$ & $-.10^{* *}$ \\
\hline 20. Cohort status & -.05 & $-.14^{* * *}$ & $-.21^{* \star *}$ & $.18^{* * *}$ & $.30^{* * *}$ & $.26^{* * *}$ & -.02 & -.00 & -.04 \\
\hline $\begin{array}{l}21 . \text { Race/ } \\
\text { ethnicity }\end{array}$ & $.08^{*}$ & .05 & .04 & .02 & $.10^{* *}$ & .00 & -.04 & .03 & .06 \\
\hline 22. Expectations ${ }^{1 t}$ & .04 & .05 & $.16^{* *}$ & $.40^{* * *}$ & $.36^{* * *}$ & $.34^{* * *}$ & $.45^{* * *}$ & $.40^{* * *}$ & $.41^{* \star *}$ \\
\hline
\end{tabular}

Note. ${ }^{1}$ Wave $1,{ }^{2}$ Wave $2,{ }^{3}$ Wave $3,{ }^{4}$ Wave $4,{ }^{\mathrm{t}}$ teachers' belief.

${ }^{* * * *} p<.001 .^{* *} p<.01 .{ }^{*} p<.05 .+p<.10$.

interest in math was also high (Table 3). In addition, when children's performance in math (W3 and W4) was high, children's concurrent interest 
Table 2. (Continued)

\begin{tabular}{llllllllllll}
\hline 10 & 11 & 12 & 13 & 14 & 15 & 16 & 17 & 18 & 19 & 20 & 21 \\
\hline
\end{tabular}

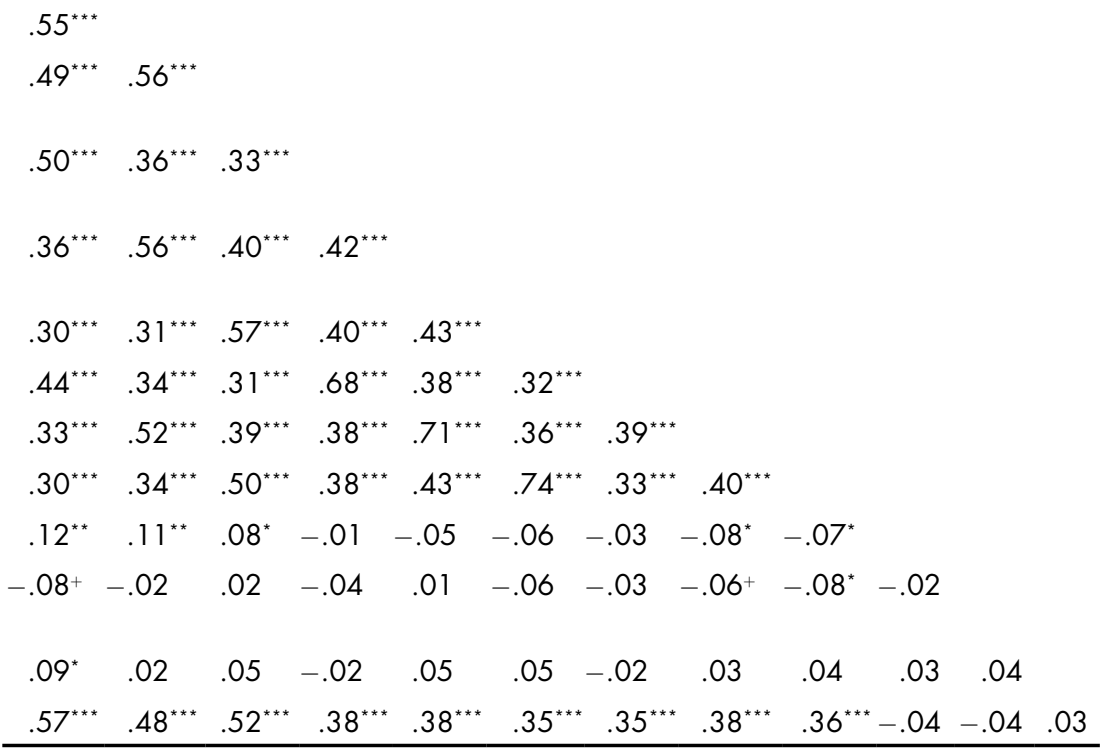

in math was also high. In addition, the previous level of children's math performance (W2) predicted an increase in children's subsequent interest in math at $\mathrm{W} 3$ and $\mathrm{W} 4$. 
Table 3. Results for the models with children's math interest, teachers' beliefs, children's performance in math, and predicting covariates

\begin{tabular}{|c|c|c|c|c|}
\hline & Effort beliefs & Ability beliefs & $\begin{array}{l}\text { Beliefs of math } \\
\text { importance }\end{array}$ & $\begin{array}{c}\text { Beliefs of math } \\
\text { performance }\end{array}$ \\
\hline $\begin{array}{l}\text { Teachers' beliefs } \\
\text { in the model }\end{array}$ & $\beta$ & $\beta$ & $\beta$ & $\beta$ \\
\hline \multicolumn{5}{|l|}{$\begin{array}{l}\text { Paths to intercept } \\
\text { construct }\end{array}$} \\
\hline Gender & $0^{*}$ & $0^{*}$ & $0^{*}$ & $0^{*}$ \\
\hline Cohort status & $-0.13^{*}$ & $-0.12^{*}$ & $-0.12^{*}$ & $0^{*}$ \\
\hline Race/ethnicity & $0.07^{*}$ & $0^{*}$ & $0.08^{*}$ & $0.07^{*}$ \\
\hline $\begin{array}{l}\text { Teachers' } \\
\text { expectations } \\
\text { (Wave 1) }\end{array}$ & $0^{*}$ & $0^{*}$ & $0^{*}$ & $0^{*}$ \\
\hline \multicolumn{5}{|l|}{$\begin{array}{l}\text { Paths to slope } \\
\text { construct }\end{array}$} \\
\hline Gender & $0.13^{* *}$ & $0.11^{*}$ & $0.10^{*}$ & $0.11^{* *}$ \\
\hline Cohort status & $-0.21^{* *}$ & $-0.20^{* *}$ & $-0.23^{* *}$ & $-0.30^{* *}$ \\
\hline Race/ethnicity & $0^{*}$ & $0^{*}$ & $0^{*}$ & $0^{*}$ \\
\hline $\begin{array}{l}\text { Teachers' } \\
\text { expectations } \\
\text { (Wave 1) }\end{array}$ & $0 *$ & $0.17^{\star *}$ & $0^{*}$ & $0^{*}$ \\
\hline
\end{tabular}

Paths to Wave 2 perception

$\begin{array}{lllll}\text { Gender } & 0^{*} & 0.11^{* *} & 0^{*} & 0^{*} \\ \text { Cohort status } & 0^{*} & 0^{*} & 0^{*} & 0^{*} \\ \begin{array}{l}\text { Race/ethnicity } \\ \text { Teachers' }\end{array} & 0^{*} & 0^{*} & 0^{*} & 0^{*} \\ \begin{array}{l}\text { expectations } \\ \text { (Wave 1) }\end{array} & 0.54^{* * *} & 0.58^{* * *} & 0.43^{* * *} & 0.37^{* *}\end{array}$

Paths to

Wave 2 math performance

\begin{tabular}{lllll} 
Gender & $0^{*}$ & $0^{*}$ & $0^{*}$ & $0 *$ \\
Cohort status & $0.21^{* * *}$ & $0.23^{* * *}$ & $0.22^{* *}$ & $0.23^{* *}$ \\
$\begin{array}{l}\text { Race/ethnicity } \\
\begin{array}{l}\text { Teachers' } \\
\text { expectations } \\
\text { (Wave 1) }\end{array}\end{array}$ & $0^{*}$ & $0^{*}$ & $0^{*}$ & $0^{*}$ \\
\hline & $0.43^{* * *}$ & $0.58^{* * *}$ & $0.45^{* * *}$ & $0.44^{* * *}$ \\
\hline
\end{tabular}


Table 3. Results for the models with children's math interest, teachers' beliefs, children's performance in math, and predicting covariates (Continued)

\begin{tabular}{|c|c|c|c|c|}
\hline \multicolumn{5}{|l|}{$\begin{array}{l}\text { Paths to Wave } \\
2 \text { math interest }\end{array}$} \\
\hline $\begin{array}{l}\text { Concurrent } \\
\text { teachers' } \\
\text { beliefs }\end{array}$ & $0.15^{* * *}$ & $0.10^{* *}$ & $0.13^{* \star *}$ & $0.09^{* *}$ \\
\hline $\begin{array}{l}\text { Concurrent } \\
\text { math } \\
\text { performance }\end{array}$ & $0^{*}$ & $0^{*}$ & $0^{*}$ & $0^{*}$ \\
\hline \multicolumn{5}{|l|}{$\begin{array}{l}\text { Paths to Wave } \\
3 \text { math interest }\end{array}$} \\
\hline $\begin{array}{l}\text { Concurrent } \\
\text { teachers' } \\
\text { beliefs }\end{array}$ & $0.12^{* * *}$ & $0^{*}$ & $0.12^{* * *}$ & $0.13^{* * *}$ \\
\hline $\begin{array}{l}\text { 1-Year prior } \\
\text { teachers' } \\
\text { beliefs }\end{array}$ & $0^{*}$ & $0^{*}$ & $0^{*}$ & $0^{*}$ \\
\hline $\begin{array}{l}\text { Concurrent } \\
\text { math } \\
\text { performance }\end{array}$ & $0.06^{*}$ & $0.12^{* \star *}$ & $0^{*}$ & $0^{*}$ \\
\hline $\begin{array}{l}\text { 1-Year } \\
\text { prior math } \\
\text { performance }\end{array}$ & $0.07^{*}$ & $0^{*}$ & $0.10^{* * *}$ & $0.09^{* *}$ \\
\hline \multicolumn{5}{|l|}{$\begin{array}{l}\text { Paths to Wave } \\
4 \text { math interest }\end{array}$} \\
\hline $\begin{array}{l}\text { Concurrent } \\
\text { teachers' } \\
\text { beliefs }\end{array}$ & $0.15^{\star \star *}$ & $0^{*}$ & $0^{*}$ & $0.13^{* * *}$ \\
\hline $\begin{array}{l}\text { 1-Year prior } \\
\text { teachers' } \\
\text { beliefs }\end{array}$ & $0^{*}$ & $0^{*}$ & $0^{*}$ & $0^{*}$ \\
\hline $\begin{array}{l}\text { 2-Year prior } \\
\text { teachers' } \\
\text { beliefs }\end{array}$ & $0^{*}$ & $0^{*}$ & $0.11^{* *}$ & $0^{*}$ \\
\hline $\begin{array}{l}\text { Concurrent } \\
\text { math } \\
\text { performance }\end{array}$ & $0.07^{*}$ & $0.12^{* \star *}$ & $0.10^{* *}$ & $0.08^{*}$ \\
\hline $\begin{array}{l}\text { 1-Year } \\
\text { prior math } \\
\text { performance }\end{array}$ & $0^{*}$ & $0^{*}$ & $0^{*}$ & $0^{*}$ \\
\hline $\begin{array}{l}\text { 2-Year } \\
\text { prior math } \\
\text { performance }\end{array}$ & $0.10^{* *}$ & $0^{*}$ & $0.08^{*}$ & $0.09^{*}$ \\
\hline
\end{tabular}

Note. ${ }^{* * *} p<.001 .{ }^{* *} p<.01 .{ }^{*} p<.05$. 
Teachers'Ability Beliefs and Children's Interest in Math

The results of the final model (Table 4) showed that when teachers believed that children had innate abilities in math (W2), children's concurrent interest in math was also high (Table 3). Moreover, when children's performance in math was high (W3 and W4), their concurrent interest in math was also high. In addition, when teachers had high expectations concerning children's math achievement, the linear slope of children's math interest was more positive. Teachers also believed boys had better math abilities than girls.

\section{Teachers' Beliefs About Math Importance and Children's Interest in Math}

The results for the final model (Table 4) showed that when teachers believed the children thought it was important to do well in math (W2 and W3), children's concurrent math interest was also high (Table 3). Teachers' beliefs about the importance of math (W2) also predicted increases in children's subsequent interest in math (W4). Moreover, when children's performance in math was high (W4), their concurrent interest in math was also high. In addition, the previous level of children's math performance (W2) predicted increases in children's subsequent interest in math (W3 and W4).

\section{Teachers' Beliefs About Children's Potential Performance and Children's Interest in Math}

The results for the final model (Table 4) showed that when teachers perceived children to be performing up to their potential in math, children's concurrent interest in math was also high over the school years. Moreover,

Table 4. Goodness-of-fit summary for the tested path models of teachers' beliefs and children's interest in math

\begin{tabular}{lcrcccccc}
\hline \multicolumn{1}{c}{ Model } & $N$ & \multicolumn{1}{c}{$\chi^{2}$} & $d f$ & $p$ & CFI & TLI & RMSEA & SRMR \\
\hline Effort & 1179 & 133.16 & 65 & 0.00 & 0.98 & 0.96 & 0.03 & 0.04 \\
Ability & 1179 & 92.13 & 32 & 0.00 & 0.94 & 0.91 & 0.04 & 0.04 \\
Importance & 1179 & 61.02 & 30 & 0.00 & 0.97 & 0.94 & 0.03 & 0.04 \\
Performance & 1179 & 85.52 & 31 & 0.00 & 0.94 & 0.90 & 0.04 & 0.04 \\
\hline
\end{tabular}

$\mathrm{CFI}=$ comparative fit index; TLI $=$ Tucker-Lewis index; RMSEA $=$ root mean square error of approximation; SRMR = standardized root mean square residual. 
when children's performance in math was high (W4), children's concurrent interest in math was also high. In addition, children's performance in math (W2) predicted an increase in children's subsequent interest in math (W3 and W4).

\section{Gender and Cohort Differences}

In order to examine whether teachers' beliefs and children's performance in math would predict children's interest in math similarly among the groups of children across cohort and gender, all analyses were also carried out by using the multisample procedure (Jöreskog \& Sörbom, 1993). In these analyses, the data were divided into two samples (boys and girls) or three samples (children in the first, second, and third cohorts). LGMs with timevarying covariates were carried out while assuming that all the paths would be equal for the different subgroups. If the fit of the model was good and no significant modification indices were found, the model was assumed to fit the subgroups equally. These results showed that all the models fit boys' and girls' data equally. The results for different cohort groups showed that all the models fit the first, second, and third cohorts' data equally, with two exceptions: In none of the models did gender $(S E=0.21, p=n s)$ or teachers' expectations ( $S E=0.26, p=n s$ ) predict the level of math interest for the second cohort's data

\section{Discussion}

In children's lives, teachers are important socializers whose beliefs about children's achievement may have consequences for the ontogeny and development of children's interest toward different academic domains. In this study, we investigated the extent to which teachers' beliefs regarding children's achievement-related behaviors predict children's interest in math across the primary school years. The results showed that teachers' beliefs about their students' effort and potential performance showed the strongest concurrent associations with children's interest in math over the school years, whereas teachers' beliefs about children's math ability predicted children's math interest to a lesser extent. Moreover, when teachers believed math was an important domain to children at the beginning of primary school, children's concurrent and subsequent interest in math was high. No gender- or age-related differences were found in the associations between teachers' beliefs and children's math interest. 
The analyses began with an examination of the developmental changes in children's math interest and teachers' beliefs. As expected, children's interest in math declined during the elementary school years. ${ }^{4}$ Similar findings have been previously reported (Eccles et al., 1993; Gottfried et al., 2001), reflecting a normative decrease in children's overall academic motivation (Wigfield \& Eccles, 2000). These changes in children's math interest may also be related to the declines in children's competence beliefs, the development of children's cognitive processing abilities, and a better understanding of evaluative feedback from teachers (Aunola et al., 2002; Bouffard et al., 1998; Eccles et al., 1997). The results further showed that teachers' beliefs followed the decrease in children's math interest, suggesting accuracy in teachers' beliefs (Jussim \& Harber, 2005). Consequently, the next aim of this study was to investigate the role of teachers' beliefs in the development of children's math interest.

\section{Teachers' Beliefs and Children's Math Interest}

The results showed first that when teachers believed children were putting a lot of effort into math, children's math interest was also high over the school years. Results from previous studies have suggested that praising children for their effort is beneficial for their future learning because it promotes interest and motivation (Dweck \& Legget, 1988), and provides children with the possibility of trying harder in the future when facing difficulties (Rytkönen, Aunola, \& Nurmi, 2005; Weiner, 1992, 1994). Moreover, while seeking social approval from their teachers, students typically explain their successes in terms of high effort (Juvonen \& Murdock, 1993). Thus, children also might perceive teachers' beliefs in students' high effort as a sign of social approval, which is reflected as an increase in children's math interest. Effort beliefs may also increase optimism in children's motivation (Rytkönen et al., 2007), which shows as high math interest. Further, children who have high interest in math and deploy task-focused behaviors are also likely to work hard and be persistent while doing their math tasks (Eccles \& Wigfield, 2002; Midgley, Kaplan, \& Middleton, 2001; Nicholls, Cobb, Wood, Yackel, \& Patashnick, 1990). Thus, teachers' beliefs concerning children's effort and persistence may partly predict children's math interest because they are accurate (Jussim \& Harber, 2005). Moreover, these findings demonstrate that teachers' beliefs about their students' effort in math can reduce the normative downward development trend in students' math interest.

4. Jacobs et al. (2002) have reported similar analyses for this sample. 
Second, it was found that when teachers believed that children had innate abilities in math, children's interest in math was also high, particularly during the early elementary years. However, later in the primary years, this association diminished, perhaps due to children's cognitive development (Bouffard et al., 1998) and understanding of the concepts of ability and effort (Eccles et al., 1983; Nicholls, 1978). At the beginning of primary school, children often think that high ability reflects high effort and vice versa (Dweck \& Elliot, 1983). However, over the school years, children start perceiving effort and ability as separate characteristics that can interact compensatorily (Dweck \& Leggett, 1988; Nicholls, 1978). Previous studies have also shown that teachers' beliefs about both ability and effort contribute to an increase in children's task motivation at the beginning of their school career (Natale et al., 2009). The present results add to these findings by showing that although changes occur in children's cognitive development and their conceptual understanding of ability and effort, this understanding also manifests in associations between teachers' beliefs and children's math interest. During the later years of primary school, teachers' beliefs in children's effort and persistence might promote children's mastery orientation toward learning (Dweck \& Leggett, 1988), which also motivates children to work harder and value math more than do teachers' beliefs in children's abilities.

Third, when teachers believed math was an important subject to children, children's concurrent and subsequent math interest was high and increased later on. These results may be partly explained by the similarity of the constructs: Teachers' beliefs both about math importance to children and about children's math interest reflect the value aspect of math motivation (Wigfield \& Eccles, 2000, 2002). Moreover, teachers are especially accurate when assessing children's math intrinsic motivation (Gottfried, 1985). Teachers' beliefs also might have been transmitted to students by modeling (Stipek et al., 2001): When teachers value math, it may show in their teaching, classroom practices, and child-related beliefs, which further increase students' math values and show as high interest toward math.

Further, when teachers believed that children were performing up to their potential in math, children's interest in math was high over the school years. Teachers tend to be less optimistic than parents about children's potential performance (Kärkkäinen \& Räty, 2010). Thus, children may value teachers' optimism about children's potential performance especially highly, which then shows as children's high math interest. Moreover, children might have perceived teachers' beliefs regarding their potential math performance as teachers' support orientation, which typically predicts children's interest in math in later grades (Midgley, Feldlaufer, \& Eccles, 1989). 
These results suggest that similar associations can be found among primary school children.

\section{The Role of Math Performance, Gender, Cohort, Ethnicity, and Expectations}

As expected, children's performance in math predicted their math interest over the school years (see also Aunola et al., 2006). Thus, during the elementary school years, math performance plays an important role in children's math interest. However, as children's math interest becomes more stable, specific performance information may have less impact on change over time.

Moreover, younger children and children from other ethnic groups had a higher level of math interest than the children in older cohorts or in the White ethnic group. Math interest also decreased more among younger than among older children. During the primary school years, children's interest in different domains typically starts to decrease (Gottfried et al., 2001); however, becoming more stable later on (Wigfield et al., 1997). Moreover, children from other ethnic groups often have higher educational expectations than children from the White ethnic group (Goyette \& Xie, 1999), which may show as higher academic interests.

Further, girls' interest in math decreased more over time than boys' math interest (Bouffard et al., 2003). Teachers also believed that boys had better math abilities, even when no differences were found in boys' and girls' actual performance. Similar results among teachers (Tiedemann, 2002) and parents (Tiedemann, 2000) have been reported previously. Thus, the results suggest that teachers' gender-stereotypic beliefs may have contributed to the decrease in girls' math interest over time. However, the associations between teachers' beliefs and children's math interest were similar for boys and girls, as well as for children in different cohort groups. Thus, girls and boys were equally sensitive to teachers' beliefs over the school years (see also Leflot, Onghena \& Colpin, 2010; Natale et al., 2009) rather than girls being more sensitive to them (Jussim, Eccles, \& Madon, 1996; Roberts, 1991).

Most of the predictions from teachers' beliefs to children's math interest were concurrent associations. In the United States, teachers of primary school children typically change every year, and all the measurements in the present study were performed during the spring term of each wave, when the teachers know their students fairly well. Moreover, different teachers likely emphasize the importance of different activities, and teachers' own interests might be reflected in their beliefs and feedback to children 
in their daily interactions (Wigfield et al., 1997), which shows as stronger concurrent associations between teachers' beliefs and children's math interest. Finally, though the teachers changed every year during the study, their expectations and beliefs regarding children's academic achievement were relatively significantly correlated across the years, suggesting that varying social actors (in our case, different teachers) perceived individual children's achievement in a similar way.

\section{Limitations}

Several limitations should be considered when generalizing the findings of the present study. First, teachers' beliefs might have predicted children's math interest partly because they are accurate (Jussim \& Harber, 2005). Second, other variables that were not studied here may have contributed to the results. For example, general social classroom climate may moderate the ways teachers' expectations and beliefs are communicated to children and thus have a different impact on children's math interest according to the classroom type (Eccles et al., 1983; Eccles-Parsons, Kaczala, \& Meece, 1982; Patrick et al., 2001). Third, some of the variables (e.g., those concerning children's performance and teachers' beliefs) correlated highly with one another, indicating that some of the results might have suffered from multicollinearity. Fourth, the study focused on examining time-varying effects of teachers' beliefs and children's math performance on children's math interest. However, children's math interest might predict their math performance and teachers' beliefs to some extent, and more studies would be needed to examine these associations in greater detail. Fifth, even though the results of the study demonstrated that teachers' beliefs predicted children's math interest, daily fluctuation may exist in the ways teachers' beliefs are communicated to their students. It will be important to investigate these processes in more detail.

\section{Conclusions}

Taken together, the results of the present study showed that teachers' beliefs regarding different aspects of children's academic achievement positively predicted children's math interest across the primary school years. Teachers' beliefs in children's innate abilities were especially important at the beginning of primary school, whereas other beliefs became increasingly important later. Our results further suggested that motivating children to put great effort into their schoolwork was beneficial for their math interest during primary school. Teachers' beliefs typically 
predict their behavior toward and feedback to children (Georgiou et al., 2002; Reyna \& Weiner, 2001), and it would be important for teachers to be aware of their beliefs and how they predict children's outcomes at different ages and grade levels. Teachers should balance between the feedback on individual children's innate abilities, effort, potential performance and motivation, and give their students the feelings of both competency and diligence (see also Craven, Marsh, \& Debus, 1991), as well as a mastery orientation and incremental views of abilities (Kamins \& Dweck, 1999). Teachers should be aware of the developmental changes that occur in children's understanding of academic abilities, effort, and performance (see also Nicholls, 1978) and give children age-appropriate feedback regarding their achievement and motivation, which would the best support children's academic motivation and learning. Similarly, interventions and teacher education programs should be targeted to increase teachers' awareness of their beliefs concerning children's math achievement and the nature of math, and their associations at different developmental stages (see also Gill, Ashton, \& Algina, 2004).

The concurrent teachers' beliefs were the most predictive for children's math interest during each year, probably because the teachers changed every year. More similar studies would be needed to examine teachers' beliefs in classrooms where teachers stay with one group of children for longer periods. It would also be important to investigate in more detail how teachers' beliefs regarding children's academic achievement are communicated to children in teacher-student interactions. Moreover, beliefs of various social actors (e.g., teachers, parents, and peers) might have different value for children and thus their beliefs may predict children's academic motivation and interests in varying ways. Future studies are needed to study these associations further.

\section{References}

Aunola, K., Leskinen, E., \& Nurmi, J.-E. (2006). Developmental dynamics between mathematical performance, task motivation, and teachers' goals during the transition to primary school. British Journal of Educational Psychology, 76, 21-40. doi:10.1348/000709905X51608b

Aunola, K., Leskinen, E., Onatsu-Arvilommi, T., \& Nurmi, J.-E. (2002). Three methods for studying developmental change: A case of reading skills and self-concept. British Journal of Educational Psychology, 72, 343-364. doi:10.1348/000709902320634447

Bouffard, T., Marcoux, M.-F. Vezeau, C., \& Bordeleau, L. (2003). Changes in self-perceptions of competence and intrinsic motivation among elementary 
schoolchildren. British Journal of Educational Psychology, 73, 171-186. doi:10.1348/00070990360626921

Bouffard, T., Markovits, H., Vezeau, C., Boisvert, M., \& Dumas, C. (1998). The relation between accuracy of self-perception and cognitive development. British Journal of Educational Psychology, 68, 321-330. doi:10.1111/j.2044-8279.1998.tb01294.x

Craven, R. G., Marsh, H. W., \& Debus, R. L. (1991). Effects of internally focused feedback and attributional feedback on enhancement of academic self-concept. Journal of Educational Psychology, 83, 17-27. doi:10.1037/0022-0663.83.1.17

Deci, E. L., Vallerand, R. J., Pelletier, L. G., \& Ryan, R. M. (1991). Motivation and education: The self-determination perspective. Educational Psychologist, 26, 325-346. doi:10.1080/00461520.1991.9653137

Duncan, T. E., Duncan, S. C., Alpert, A., Hops, H., Stoolmiller, M., \& Muthén, B. (1997). Latent variable modeling of longitudinal and multilevel substance use data. Multivariate Behavioral Research, 32, 275-318. doi:10.1207/ s15327906mbr3203_3

Dweck, C. S. (1986). Motivational processes affecting learning. American Psychologist, 41, 1040-1048. doi:10.1037/0003-066X.41.10.1040

Dweck, C. S., Davidson, W., Nelson, S., \& Enna, B. (1978). Sex differences in learned helplessness: II. The contingencies of evaluative feedback in the classroom and III. An experimental analysis. Developmental Psychology, 14, 268-276. doi:10.1037/0012-1649.14.3.268

Dweck, C. S., \& Elliot, E. S. (1983). Achievement motivation. In P. H. Mussen (Ed.), Handbook of child psychology: Vol. 4. Socialization, personality and social development (4th ed., pp. 643-691). New York: Wiley.

Dweck, C. S., \& Leggett, E. L. (1988). A social-cognitive approach to motivation and personality. Psychological Review, 95, 256-273. doi:10.1037/0033-295X.95.2.256

Eccles, J. S., Adler, T. F., Futterman, R., Goff, S. B., Kaczala, C. M., Meece, J., \& Midgley, C. (1983). Expectancies, values, and academic behaviors. In T. J. Spence (Ed.), Achievement and academic motives (pp. 75-146). New York: Freeman.

Eccles, J. S., Adler, T., \& Meece, J. L. (1984). Sex differences in achievement: A test of alternate theories. Journal of Personality and Social Psychology, 46, 26-43. doi:10.1037/0022-3514.46.1.26

Eccles, J. S., \& Wigfield, A. (1995). In the mind of the actor: The structure of adolescents' achievement task value and expectancy-related beliefs. Personality and Social Psychology Bulletin, 21, 215-225. doi:10.1177/0146167295213003

Eccles, J. S., \& Wigfield, A. (2002). Motivational beliefs, values, and goals. Annual Review of Psychology, 53, 109-132. doi:10.1111/1467-8624.00421

Eccles, J. S., Wigfield, A., Harold, R. D., \& Blumenfeld, P. (1993). Age and gender differences in children's self- and task perceptions during elementary school. Child Development, 64, 830-847. doi:10.1111/j.1467-8624.1993.tb02946.x 
Eccles, J. S., Wigfield, A., \& Schiefele, U. (1997). Motivation to succeed. In W. Damon \& N. Eisenberg (Eds.), Handbook of child psychology: Vol. 3. Social, emotional, and personality development (5th ed., pp. 1017-1095). New York: Wiley.

Eccles-Parsons, J. S., Kaczala, C. M., \& Meece, J. L. (1982). Socialization of achievement attitudes and beliefs: Classroom influences. Child Development, 53, 322-339. doi:10.2307/1128974

Frome, P., \& Eccles, J. S. (1998). Parents' influence on children's achievementrelated perceptions. Journal of Personality and Social Psychology, 74, 435-452. doi:10.1037/0022-3514.74.2.435

Georgiou, S., Christou, C., Stavrinides, P., \& Panaoura, G. (2002). Teacher attributions of student failure and teacher behavior toward the failing student. Psychology in the Schools, 39, 583-595. doi:10.1002/pits.10049

Gill, M. G., Ashton, P. T., \& Algina, J. (2004). Changing preservice teachers' epistemological beliefs about teaching and learning in mathematics: An intervention study. Contemporary Educational Psychology, 29, 164-185. doi:10.1016/j. cedpsych.2004.01.003

Gottfried, A. E. (1985). Academic intrinsic motivation in elementary and junior high school students. Journal of Educational Psychology, 77, 631-645. doi:10.1037/0022-0663.77.6.631

Gottfried, A. E. (1990). Academic intrinsic motivation in young elementary school children. Journal of Educational Psychology, 82, 525-538. doi:10.1037/0022-0663.82.3.525

Gottfried, A. E., Fleming, J. S., \& Gottfried, A. W. (2001). Continuity of academic intrinsic motivation from childhood through late adolescence: A longitudinal study. Journal of Educational Psychology, 93, 3-13. doi:10.1037/0022-0663.93.1.3

Goyette, K., \& Xie, Y. (1999). Educational expectations of Asian American youths: Determinants and ethnic differences. Sociology of Education, 72, 22-36. doi: $10.2307 / 2673184$

Graham, S. (1984). Teachers feelings and student thoughts: An attributional approach to affect in the classroom. Elementary School Journal, 85, 90-104.

Graham, S. (1990). Communicating low ability in the classroom: Bad things good teachers sometimes do. In S. Graham \& V. S. Folkes (Eds.), Attribution theory: Applications to achievement, mental health, and interpersonal conflict (pp. 17-36). Hillsdale, NJ: Erlbaum.

Harter, S. (1981). A new self-report scale of intrinsic versus extrinsic orientation in the classroom: Motivational and informational components. Developmental Psychology, 17, 300-312. doi:10.1037/0012-1649.17.3.300

Herbert, J., \& Stipek, D. (2005). The emergence of gender differences in children's perceptions of their academic competence. Applied Developmental Psychology, 26, 276-295. doi:10.1016/j.appdev.2005.02.007 
Holloway, S. D., \& Hess, R. D. (1985). Mothers' and teachers' attributions about children's mathematical performance. In I. E. Siegel (Ed.), Parental belief systems: The psychological consequences for children (pp. 177-199). Hillsdale, NJ: Erlbaum.

Hughes, J. N., Gleason, K. A., \& Zhang, D. (2005). Relationship influences on teachers' perceptions of academic competence in academically at-risk minority and majority first grade students. Journal of School Psychology, 43, 303-320. doi:10.1016/j.jsp.2005.07.001

Jacobs. J. E., \& Eccles, J. S. (2000). Parents, task values, and real-life achievement-related choices. In C. Samsone \& J. M. Harackiewicz (Eds.), Intrinsic and extrinsic motivation: The search for optimal motivation and performance (pp. 405-439). San Diego, CA: Academic Press.

Jacobs, J. E., Lanza, S., Osgood, D. W., Eccles, J. S., \& Wigfield, A. (2002). Changes in children's self-competence and values: Gender and domain differences across grades one through twelve. Child Development, 73, 509-527. doi:10.1111/1467-8624.00421

Jussim, L. (1989). Teacher expectations: Self-fulfilling prophecies, perceptual biases, and accuracy. Journal of Personality and Social Psychology, 57, 469-480. doi:10.1037/0022-3514.57.3.469

Jussim, L., Eccles, J., \& Madon, S. (1996). Social perception, social stereotypes, and teacher expectations: Accuracy and the quest for the powerful self-fulfilling prophecy. Advances in Experimental Social Psychology, 28, 281-388. doi:10.1016/S0065-2601(08)60240-3

Jussim, L., \& Harber, K. D. (2005). Teacher expectations and self-fulfilling prophecies: Knowns and unknowns, resolved and unresolved controversies. Personality and Social Psychology Review, 9, 131-155. doi:10.1207/ s15327957pspr0902_3

Jöreskog, K. G., \& Sörbom, D. (1993). LISREL 8: Structural equation modeling with the SIMPLIS command language. Hillsdale, NJ: Erlbaum.

Juvonen, J., \& Murdock, T. B. (1993). How to promote social approval: Effects of audience and achievement outcome on publicly communicated attributions. Journal of Educational Psychology, 85, 365-376. doi:10.1037/0022-0663.85.2.365

Juvonen, J., \& Murdock, T. B. (1995). Grade-level differences in the social value of effort: Implications for self-presentation tactics of early adolescents. Child Development, 66, 1694-1705. doi:10.1111/j.1467-8624.1995.tb00959.x

Kamins, M. L., \& Dweck, C. S. (1999). Person versus process praise and criticism: Implications for contingent self-worth and coping. Developmental Psychology, 35, 835-847. doi:10.1037/0012-1649.35.3.835

Kärkkäinen, R., \& Räty, H. (2010). Parents' and teachers' views of the child's academic potential. Educational Studies, 36, 229-232. doi:10.1080/03055690903162424 
Leflot, G., Onghena, P., \& Colpin, H. (2010). Teacher-child interactions: Relations with children's self-concept in second grade. Infant and Child Development, 19, 385-405. doi:10.1002/icd.672

Madon, S., Jussim, L., Keiper, S., Eccles, J., Smith, A., \& Palumbo, P. (1998). The accuracy and power of sex, social class, and ethnic stereotypes: A naturalistic study in person perception. Personality and Social Psychology Bulletin, 24, 1304-1318. doi:10.1177/01461672982412005

Midgley, C., Feldlaufer, H., \& Eccles, J. S. (1989). Student/teacher relations and attitudes toward mathematics before and after the transition to junior high school. Child Development, 60, 981-992. doi:10.2307/1131038

Midgley, C., Kaplan, A., \& Middleton, M. (2001). Performance-approach goals: Good for what, for whom, under what circumstance, and at what cost? Journal of Educational Psychology, 93, 77-86. doi:10.1037/0022-0663.93.1.77

Murphy, P. K., \& Alexander, P. A. (2000). A motivated exploration of motivation terminology. Contemporary Educational Psychology, 25, 3-53. doi:10.1006/ ceps.1999.1019

Murray, C. B. (1996). Estimating achievement and performance: A confirmation bias. Journal of Black Psychology, 22, 6-85. doi:10.1177/00957984960221006

Muthén, L., \& Muthén, B. O. (1998-2014). Mplus user's guide. Los Angeles: Muthén \& Muthén. Retrieved from www.statmodel.com/download/usersguide/ Mplus\%20Users\%20Guide\%20v6.pdf.

Natale, K., Viljaranta, J., Lerkkanen, M.-K. Poikkeus, A.-M. \& Nurmi, J.-E. (2009). Cross-lagged associations between kindergarten teachers' causal attributions and children's task motivation and performance in reading. Educational Psychology, 29, 603-619. doi:10.1080/01443410903165912

Nicholls, J. G. (1978). The development of the concepts of effort and ability, perception of academic attainment, and the understanding that difficult tasks require more ability. Child Development, 49, 800-814. doi:10.2307/ 1128250

Nicholls, J. G., Cobb, P., Wood, T., Yackel, E., \& Patashnick, M. (1990). Assessing students' theories of success in mathematics: Individual and classroom differences. Journal for Research in Mathematics Education, 21, 109-122. doi:10.1007/BF00369293

Patrick, H., Anderman, L. H., Ryan, A. M., Edelin, K. C., \& Midgley, C. (2001). Teachers' communication of goal orientations in four fifth-grade classrooms. Elementary School Journal, 102, 35-58. doi:10.1086/499692

Reyna, C., \& Weiner, B. (2001). Justice and utility in the classroom: An attributional analysis of the goals of teachers' punishment and intervention strategies. Journal of Educational Psychology, 93, 309-319. doi:10.1037/0022-0663. 93.2.309

Roberts, T.-A. (1991). Gender and the influence of evaluations on selfassessments in achievement settings. Psychological Bulletin, 109, 297-308. doi:10.1037/0033-2909.109.2.297 
Ryan, R. M., \& Deci, E. L. (2000). Intrinsic and extrinsic motivations: Classic definitions and new directions. Contemporary Educational Psychology, 25, 54-67. doi:10.1006/ceps.1999.1020

Rytkönen, K., Aunola, K., \& Nurmi, J.-E. (2005). Parents' causal attributions concerning their children's school achievement: A longitudinal study. MerrillPalmer Quarterly, 51, 494-522. doi:10.1353/mpq.2005.0027

Rytkönen, K., Aunola, K., \& Nurmi, J.-E. (2007). Do parents' causal attributions predict the accuracy and bias of their children's self-concept of math ability? A longitudinal study. Educational Psychology 27, 771-788. doi:10.1080/01443410701309316

Schiefele, U. (1996). Topic interest, text representation, and quality of experience. Contemporary Educational Psychology, 2, 3-18. doi:10.1006/ceps. 1996.0002

Spinath, B., \& Spinath, F. M. (2005). Development of self-perceived ability in elementary school: The role of parents' perceptions, teacher evaluations, and intelligence. Cognitive Development, 20, 190-204. doi:10.1016/j. cogdev.2005.01.001

Stipek, D. J., Givvin, K. B., Salmon, J. M., \& MacGyvers, V. L. (2001). Teachers' beliefs and practices related to mathematics instruction. Teaching and Teacher Education, 17, 213-226. doi:10.1016/S0742-051X(00)00052-4

Tiedemann, J. (2000). Parents' gender stereotypes and teachers' beliefs as predictors of children's concept of their mathematical ability in elementary school. Journal of Educational Psychology, 92, 144-151. doi:10.1037/0022-0663.92.1.144

Tiedemann, J. (2002). Teachers' gender stereotypes as determinants of teacher perceptions in elementary school mathematics. Educational Studies in Mathematics, 50, 49-62. doi:10.1023/A:1020518104346

Upadyaya, K., \& Eccles, J. S. (2014). Do teachers' perceptions of children's math and reading related ability and effort predict children's self-concept of ability in math and reading? Educational Psychology, 18 pp. doi:10.1080/01443410. 2014.915927

Upadyaya, K., Viljaranta, J., Lerkkanen, M.-K. Poikkeus, A.-M. \& Nurmi, J.-E. (2012). Cross-lagged relations between preschool teachers' causal attributions and children's interest value and performance in math. Social Psychology of Education, 15, 181-206. doi:10.1007/s11218-011-9171-1

Weiner, B. (1992). Human motivation: Metaphors, theories, and research. Newbury Park, CA: Sage.

Weiner, B. (1994). Integrating social and personal theories of achievement striving. Review of Educational Research, 64, 557-573. doi:10.3102/ 00346543064004557

Wigfield, A., \& Eccles, J. E. (1994). Children's competence beliefs, achievement values, and general self-esteem. Journal of Early Adolescence, 14, 107-138. doi:10.1177/027243169401400203 
Wigfield, A., \& Eccles, J. S. (2000). Expectancy-value theory of achievement motivation. Contemporary Educational Psychology, 25, 68-81. doi:10.1006/ ceps.1999.1015

Wigfield, A., \& Eccles, J. S. (2002). The development of competence beliefs, expectancies for success, and achievement values from childhood through adolescence. In A. Wigfield, J. S. Eccles \& the Institute for Research on Women and Gender (Eds.), Development of Achievement Motivation (pp. 91-120). San Diego, CA: Academic Press.

Wigfield, A., Eccles, J. S., \& Rodriquez, D. (1998). The development of children's motivation in school contexts. Review of Research in Education, 23, 73-118. doi:10.2307/1167288

Wigfield, A., Eccles, J. S., Suk Yoon, K., Harold, R. D., Arbreton, A. J. A., Freedman-Doan, C., \& Blumenfield, P. C. (1997). Change in children's competence beliefs and subjective task values across the elementary school years: A 3-year study. Journal of Educational Psychology, 89, 451-469. doi:10.1037/0022-0663.89.3.451 